[Vol. 11

\begin{tabular}{|c|c|c|c|c|c|c|}
\hline $\begin{array}{c}d-l-a \text { amino- } n \\
\text { butyric acid }\end{array}$ & act. amylalc. & 81.5 & 32.5 & 79 & $0.6(13.2 \mathrm{~L})^{\prime}$ & - \\
\hline$d-l-n$-valine & $n$-butylalc. & 70.5 & 57 & 70 & $3.5(30)$ & 49 \\
\hline$d-l$. valine & $\begin{array}{l}\text { amylalc. B. } \\
\text { P. }\left(123 \sim 30^{\circ}\right)\end{array}$ & 65 & $40 \sim 43$ & 59 & $30.36(30)$ & $40^{*}$ \\
\hline$d-l$. leucine & isoamylalc. & 63 & 57.5 & - & $2.0(23)$ & 38 \\
\hline asparagine & & - & - & - & $4.0(30)$ & 84.5 \\
\hline$\underset{\text { acid }}{\operatorname{glutaminic}}$ & amylalc. & - & - & - & $24(30)$ & 88 \\
\hline control & $\begin{array}{c}\text { trace of amyl } \\
\text { alc. }\end{array}$ & & & & $3.0(20)$ & $54^{*}$ \\
\hline
\end{tabular}

* together with added yeast.

\title{
On the Glycerin Fraction in saké.
}

\author{
By Masakazu YAMADA \\ (Received October 29, 1934)
}

(1) The glycerin fraction of sake $(10 \mathrm{~L})$ and moto-mash $(50 \mathrm{~L})$ were isolated by ordinary alcohol-ether extraction method from the extracts and $0.384 \%$ in saké and $0.754 \%$ in moto-mash were found. The fraction consists of $2 \cdot 3$-butylenglycol (B. P. $177 \sim 185^{\circ}$ ) and glycerin (B. P. $156 \sim 169^{\circ} / 7 \mathrm{~mm}$ ). The ratio of two compounds are $1: 20$ in saké and 1:10 in moto mash.

(2) Diphenyl-carbamate of $2 \cdot 3$-butylenglycol prepared melts at $201^{\circ}$ and contains nitrogen $8.61 \%\left(8.54 \%\right.$ calculated for $\left.\mathrm{C}_{18} \mathrm{H}_{20} \mathrm{~N}_{2} \mathrm{O}_{4}\right)$.

(3) Specific rotatory power of butylenglycol :

$$
[\alpha]_{D}^{320}=+9.70
$$

(4) Both constituents are necessary for the refined seweet taste of saké.

\section{On the Variation of Sugar-content in saké.}

\author{
By Masakazu YAMADA \\ Katsuichirō TAKAGISHI \\ (Governmental Institute of Brewing, Takinogawa, Tokyo.)
}

(Received October 29, 1934)

The sweet taste of saké is mainly due to sugar in it, while we found that sugar content was not constant but increased day by day with average speed of $0.0284 \%$ a day until pasteurization after the stage of compression of ' moromi.**

* Moromi $=$ saké lees. 